\title{
Lymphocyte Subsets in Synovial Fluid from Clinically Healthy Joints of Dogs
}

\author{
M. FALDYNA ${ }^{1,2}$, J. ZATLOUKAL ${ }^{2}$, L. LEVA ${ }^{1}$, A. NEČAS ${ }^{2}$, M. TOMAN $^{1,2}$
}

${ }^{1}$ Veterinary Research Institute, Brno, Czech Republic

2 University of Veterinary Medicine and Pharmaceutical Sciences Brno, Czech Republic

Received August 8, 2003

Accepted February 11, 2004

\section{Abstract}

Faldyna, M., J. Zatloukal, L. Leva, A. Necas, M. Toman: Lymphocyte Subsets in Synovial Fluid from Clinically Healthy Joints of Dogs. Acta Vet. Brno 2004, 73: 73-78.

Synovial fluid samples from 19 normal (without lameness, pain, macroscopic and roentgenological changes) knees of 12 dogs were investigated for differential leukocyte counts and lymphocyte subsets using the methods of flow cytometry and anti-canine monoclonal antibodies. In all the samples, less than $5 \times 10^{6}$ leukocytes per millilitre were detected. Neutrophils and lymphocytes constituted less than $5 \%$ and more than $90 \%$ of all leukocytes, respectively. Tlymphocytes characterized by the expression of CD4 or CD8 were found to be the predominant types in this compartment. In comparison with peripheral blood, the CD4/CD8 ratio was decreased $(0.8 \pm 0.6$ vs. $3.3 \pm 1.1)$. Majority of lymphocytes expressed the CD45RA isoform $(69.4 \pm 16.7)$. This study is the first step to subsequent analyses of changes in this compartment caused by joint diseases of different aetiologies.

Flow cytometry, CD antigen

There are two types of joint diseases in dogs: inflammatory and degenerative arthropathies (Bennett and May 1995). Inflammatory arthropathies can be divided by pathogenesis into two groups - bacterial infectious arthritis (Bennett and Taylor 1987) and immunemediated arthritis. The latter includes canine rheumatoid arthritis (Bennett 1987ab), polyarthritis associated with systemic lupus erythematosus (Bennett 1987c), idiopathic polyarthritis (Bennett 1987d), and polyarthritis/polymyositis syndrome (Bennett and Kelly 1987). Canine rheumatoid arthritis has many clinical, radiological and pathological similarities to human rheumatoid arthritis (Schumacher et al. 1980; Bennett 1987b). The aetiology of rheumatoid arthritis, both canine and human, is unknown. However, there is no doubt about an important role of the immune system in pathogenesis of rheumatoid arthritis, and many autoimmune mechanisms have been described to be involved (B ari et al. 1989; Carter et al. 1989; Bell et al. 1997).

Many features of autoimmunity have also been reported in degenerative arthropathies which involve osteoarthritis, caused mainly by the rupture of cranial cruciate ligament. Increased levels of synovial fluid rheumatoid factors (Carter et al. 1989), immune complexes (Niebauer and Menzel 1982; Carter et al. 1989), and antibodies to collagen (Niebauer et al. 1987; B ari et al. 1989) have been described.

Although a role of cell-mediated immunity in pathogenesis of joint diseases in humans has been proposed (Bertouch et al. 1984; Reme et al. 1990; Keystone et al. 1991; Sohen et al. 1991; Panayi et al. 1992; al-Janadi et al. 1993; Kuryliszyn-Moskal 1995; Kusaba et al. 1998; Smeets et al. 1998; Costello et al. 1999; Y amamura et al. 2001), only two papers dealing with immunohistochemical characterisation of lymphocyte subsets in synovial membranes of dogs with rheumatoid arthritis and degenerative joint disease have been published (May et al. 1992; Hewicker-Trautwein et al. 1999).

Both of them described immunohistochemical detection of lymphocyte subsets in synovial membranes of dogs with rheumatoid arthritis and degenerative joint disease. In the

\begin{tabular}{ll}
\hline Address for correspondence: & Phone +420541321241 \\
MVDr. Martin Faldyna, Ph.D. & Fax +420541211229 \\
Veterinary Research Institute & e-mail: faldyna @vi.cz \\
Hudcova 70, 621 32 Brno, Czech Republic & http://www.vfu.cz/acta-vet/actavet.htm
\end{tabular}


papers cited above, samples from normal joints of three and five healthy dogs, respectively, were used as a control. May et al. (1992) used cross reacting anti-murine IgM monoclonal antibody, anti-dog monoclonal antibody against Thy-1, and anti-dog polyclonal antibodies against IgG and IgA. They did not find any marked B-lymphocyte or T-lymphocyte staining in specimens from normal joints. In a similar study with different monoclonal antibodies, Hewicker-Trautwein et al. (1999) found T-lymphocytes $\left(\mathrm{CD}^{+} / 4^{+}\right.$or $\left.\mathrm{CD}^{+} / 8^{+}\right)$to be present in low numbers (less than 5 or up to 15 , respectively), mainly within the superficial subsynovial tissue of normal joints. When monoclonal antibodies against gamma-delta Tcells and CD21 (B-lymphocytes) were used, no reactivity was seen.

Flow cytometry analysis, contrary to immunohistochemistry, allows less invasive sample collection. Since this method has not been used in canine medicine, we used flow cytometry for characterisation of lymphocyte populations in synovial fluid from healthy joints of dogs as the first step to subsequent analyses of changes in this compartment caused by joint diseases of different etiologies.

\section{Materials and Methods}

Animals

Samples of synovial fluid from 24 normal (without pain, macroscopic and roentgenological changes) knees of 12 dogs were collected. Five samples were excluded because of visible blood contamination. Therefore 19 samples were included in the study. The dogs were euthanised for different reasons. More characteristics of dogs are shown in Table 1. For comparison of the compartments, samples of peripheral blood were perioperative or collected by venipuncture immediately before euthanasia.

Table 1

Animals investigated in the study

\begin{tabular}{|c|lcl|}
\hline Dog & Breed & Age & Diagnosis \\
\hline 1 & Central Asia Shepherd Dog & $7 \mathrm{~m}$ & bilateral hip dysplasia, rupture of right lig. \\
& & & capitis femoris \\
2 & Rottweiler & $8 \mathrm{~m}$ & persistent ductus arteriosus \\
3 & German Shepherd & $9 \mathrm{~m}$ & tibia fracture \\
4 & Doberman Pinscher & $10 \mathrm{~m}$ & head trauma \\
5 & Labrador Retriever & $10 \mathrm{~m}$ & bilateral hip dysplasia \\
6 & Labrador Retriever & $10 \mathrm{~m}$ & atrial septal defect \\
7 & German Shepherd & $2 \mathrm{y}$ & spinal cord thromboembolisation \\
8 & Rottweiler & $5 \mathrm{y}$ & bilateral hip dysplasia \\
9 & Golden Retriever & $5 \mathrm{y}$ & bilateral hip dysplasia \\
10 & Rhodesian Ridgeback & $5 \mathrm{y}$ & avulsion of plexus brachalis \\
11 & Dalmatian & $7 \mathrm{y}$ & Wobbler syndrom \\
12 & Doberman Pinscher & $9 \mathrm{y}$ & Wobbler syndrom \\
\hline
\end{tabular}

Cytological evaluation

Total leukocyte counts were determined using the Coulter Counter (Coulter Electronics Ltd., Harpenden Hearts, England). Differential leukocyte counts were enumerated from smears stained with May-Grünwald and GiemsaRomanowski.

Immunostaining and flow cytometry

The synovial fluid samples for flow cytometry were processed within two hours after collection. Samples were centrifuged and the supernatants were then gathered and stored in refrigerator for further study. The remaining sediments were subsequently stained.

Indirect immunofluorescence was used for single colour flow cytometry as described elsewhere (Faldyna et al. 2001). The cells were incubated with mouse anti-dog monoclonal antibodies (Table 2) and Fc-receptor-mediated binding was blocked by adding heat-inactivated non-immune swine serum. After a 15 min incubation, the cell suspension was washed in a lysing solution $\left(8.3 \mathrm{~g} \mathrm{NH}_{4} \mathrm{Cl}, 1 \mathrm{~g} \mathrm{KHCO}_{4}\right.$ and $1 \mathrm{mM}^{\mathrm{m} D T A}$ per liter of distilled water). Binding of primary immunoreagents was visualized with fluorescein isothiocyanate-labelled swine anti-mouse immunoglobulin (Sevapharma Prague, Czech Rep.; diluted 1:360). Negative control samples were labelled with the secondary antibody only. After a 20 min incubation with the secondary antibody, cells were washed in a washing 
buffer (PBS containing $0.1 \%$ sodium azide and 0.05 mM EDTA, all reagents from Sigma). Propidium iodide was used for staining DNA in dead and damaged cells and exclusion of these events from analysis. Samples of peripheral blood were stained using the whole-blood lysis technique (Faldy na et al. 2001).

Detection of CD45 and SWC3 antigen was used for assessment of "gate purity" as described elsewhere (Faldyna et al. 2001). The antigen CD45 is expressed on all leukocytes and SWC3 is not expressed on lymphocytes. Therefore, only cells positive for CD45 and negative for SWC3 should belong to lymphocytes.

Data were acquired on the standard FACSCalibur ${ }^{\mathrm{TM}}$ flow cytometer (Becton Dickinson, Mountain View, CA) operated by the CELLQuest software. In each sample, at least 5000 cells were measured and the data were saved in the list mode. The WinMDI software was used for data analyses.

Table 2

Mouse monoclonal antibodies used in the study

\begin{tabular}{|l|llll|}
\hline mAb & Specificity & Isotype & Distribution & Source \\
\hline CA13.1E4 & caCD4 & IgG1 & Helper T-cell subset & P. F. Moore \\
CA9.JD3 & caCD8 & IgG2a & Subsets of T and NK cells & P. F. Moore \\
CA2.1D6 & caCD21 & IgG1 & B- cell lineage & P. F. Moore \\
CA20.8H1 & caTCR $\gamma \delta$ & IgG2a & $\gamma \delta$ T-cells & P. F. Moore \\
CA12.10C12 & caCD45 & IgG1 & All leukocytes & P. F. Moore \\
CA4.1D3 & caCD45RA & IgG1 & B cells, T cell subset & P. F. Moore \\
DH59B* & SWC3 & IgG1 & Phagocytes, progenitors & VMRD, Inc. $^{2}$ \\
\hline
\end{tabular}

${ }^{1}$ School of Veterinary Medicine, University of California, Davis, CA, U.S.A.

2 VMRD (Veterinary Medical Research and Development), Inc., Pullman, WA, U.S.A.

* Monoclonal antibody DH59B raised against other species reacted with canine homologues of surface molecules; SWC3 (Swine Workshop Cluster 3), is a member of Signal Immunoregulatory Protein-like family

Statistical evaluation

Means and standard deviations were calculated for characterisation of synovial fluid lymphocyte compartments. Inter-compartment differences were evaluated using Mann-Whitney $U$-test for non-parametric comparisons. All calculations were performed with Prizma ${ }^{\circledR}$ (Graph Pad Software, Inc.) software.

\section{Results}

Total and differential leukocyte counts in synovial fluid

In all synovial fluid samples, less than $5 \times 10^{6}$ leukocytes per millilitre were detected. Neutrophils and lymphocytes constituted less than 5\% and more than $90 \%$ of all leukocytes, respectively, as determined by light microscopy.

Lymphocyte subsets in synovial fluid

The sample processing used in the present study allowed us to distinguish leukocyte subsets by light scatter characteristics. Lympho-gate was distinguishable from other cell types (Fig. 1). It should be noted that, similarly to peripheral blood, it was difficult to make a distinction between monocytes and granulocytes in synovial fluid samples by light scatter characteristics.
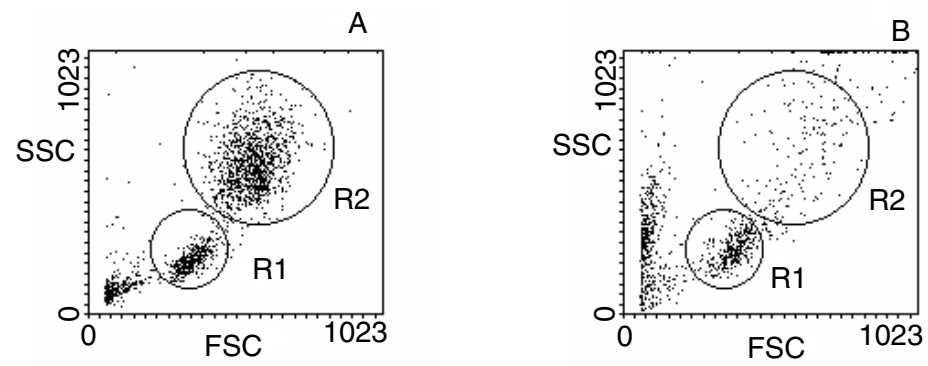

Fig. 1. Light scatter characteristics of leukocytes from peripheral blood (A) and synovial fluid from a healthy joint (B). Lymphocytes are marked R1, granulocytes and monocytes/macrophages are marked R2. 
About $90 \%$ of cells in the lympho-gate were positive for the common leukocytic antigen CD45. Less than 3\% of cells in this region were positive for SWC3 antigen, which is expressed on the surface of the myeloid lineage. It means that almost all the cells in the lympho-gate belonged to lymphocytes. Distribution of lymphocyte subsets in synovial fluid is shown in Table 3. No difference in two joints from the same dog was found.

In comparison with the results obtained from peripheral blood samples (Table 4), synovial fluid from healthy joints contained a lower proportion of CD4 and CD21 positive lymphocytes. The proportions of CD8, $\gamma \delta$-TCR, and CD45RA positive lymphocytes were comparable to those in peripheral blood. The CD4/CD8 ratio was higher in peripheral blood than in synovial fluid.

Table 3

Lymphocyte subsets in synovial fluid from 19 healthy joints of $12 \mathrm{dogs}$

\begin{tabular}{|lr|ccc|}
\hline Parameter & & Mean \pm SD & Median & Range \\
\hline CD45RA+ & $\%$ & $69.4 \pm 16.7$ & 64.1 & $46.7-92.1$ \\
CD4+ & $\%$ & $13.6 \pm 9.5$ & 8.5 & $3.8-41.5$ \\
CD8+ & $\%$ & $16.5 \pm 7.5$ & 16.7 & $4.9-31.5$ \\
CD4/CD8 & ratio & $0.8 \pm 0.6$ & 0.9 & $0.2-2.6$ \\
$\gamma \delta$-TCR+ & $\%$ & $1.9 \pm 2.1$ & 1.5 & $0.0-7.9$ \\
CD21+ & $\%$ & $2.2 \pm 3.1$ & 1.0 & $0.0-13.0$ \\
\hline
\end{tabular}

Table 4

Lymphocyte subsets in synovial fluid and peripheral blood

\begin{tabular}{|lc|ccc|}
\hline Parameter & & Synovial fluid & Peripheral blood & Significance \\
\hline CD45RA+ & $\%$ & $69.4 \pm 16.7$ & $74.5 \pm 13.2$ & n.s. \\
CD4+ & $\%$ & $13.6 \pm 9.5$ & $46.3 \pm 8.8$ & $p<0.01$ \\
CD8+ & $\%$ & $16.5 \pm 7.5$ & $15.0 \pm 4.9$ & n.s. \\
CD4/CD8 & ratio & $0.8 \pm 0.6$ & $3.3 \pm 1.1$ & $p<0.01$ \\
$\gamma \delta$-TCR+ & $\%$ & $1.9 \pm 2.1$ & $2.9 \pm 2.3$ & n.s. \\
CD21+ & $\%$ & $2.2 \pm 3.1$ & $16.8 \pm 8.7$ & $p<0.01$ \\
\hline
\end{tabular}

n.s. not significant

\section{Discussion}

To our knowledge, only two papers dealing with lymphocyte subsets in dog joints have been published so far (May et al. 1992; Hewicker-Trautwein et al. 1999). No paper describing lymphocytes in synovial fluid from dog joints has been published up to now. Therefore, in this study, we used this method for the characterization of lymphocyte subsets in synovial fluid from healthy joints of dogs.

Since no data about counts of lymphocyte subsets in healthy joints are available, we cannot compare our results with results from another species. We found T-lymphocytes characterized by the expression of CD4 or CD8 to be predominant types in that compartment with lower CD4/CD8 ratio when compared with peripheral blood. Majority of lymphocytes expressed the CD45RA isoform. Expression of CD45RA is related to B-lymphocytes and to virgin T-lymphocytes. As we found B-lymphocytes to comprise a minor population of lymphocytes, we concluded that majority of T-lymphocytes in healthy joints were unprimed by antigen.

When we compared our results with data published about lymphocyte subsets in other compartments (Dirscherl et al. 1995; Vail et al. 1995; Tipold et al. 1998) we found that synovial fluid is the only compartment in which CD8 predominates over CD4 (at least in group analysis). On the other hand, percentage of CD45RA lymphocytes in synovial fluid is higher than in other compartments studied. 
When we summed the percentages of all major subsets of synovial fluid lymphocytes, we reached only a half of the sum obtained in peripheral blood. There might be three explanations or a combination of them: (1) A portion of the antigens was covered by proteins from synovial fluid. Because of small volumes of specimens, particulary from normal joints, we were not able to follow the techniques of sample processing described in papers dealing with synovial fluid lymphocytes of humans. It was impossible to use the staining of lymphocytes after their separation by gradient centrifugation usually employed in those studies. However, the expression of CD45 on almost all cells in the lympho-gate practically ruled out this explanation. (2) Many events in the lympho-gate were not lymphocytes. The results obtained could only partly be accounted for that fact. It was found that about $90 \%$ of events in the lympho-gate were CD45 positive which was the evidence that those cells belonged to leukocytes. Based on the absence of SWC3-antigen which is expressed on monocytes and granulocytes, it could be concluded that almost all the cells in the lymphogate belonged to lymphocytes. (3) There was another lymphocyte subset present which was not detected by monoclonal antibodies used.

Relatively high variance of results obtained from healthy joints rules out the possibility to use this method for improvement of individual diagnosis. Similar situation was found also in other compartments such as cerebrospinal fluid (Tipold et al. 1998). We think, however, that the method can be useful for studies of joint disease pathogenesis based on inter-group comparison.

\section{Subpopulace lymfocytů v synoviální tekutině zdravých kloubů psů}

Diferenciální rozpočet leukocytů a subpopulace lymfocytů byly detekovány ve vzorcích synoviální tekutiny z 19 zdravých (bez kulhání, bolestivosti, makroskopických a rentgenologických změn) kolenních kloubů 12 psů. Pro stanovení subpopulací lymfocytů byly použity monoklonální protilátky proti diferenciačním antigenům psích lymfocytů a analýza byla provedena metodou průtokové cytometrie. Ve všech vzorcích bylo nalezeno méně než $5 \times 10^{6}$ leukocytů v mililitru tekutiny. Neutrofily představovaly méně než $5 \%$ a lymfocyty více $90 \%$ všch leukocytů. T-lymfocyty charakterizované expresí antigenů CD4 nebo CD8 představovaly predominantní typ lymfocytů v tomto kompartmentu. Poměr CD4/CD8 lymfocytů byl v synoviální tekutině, ve srovnání v periferní krví, nižší - 0,8 \pm 0,6 vs. $3,3 \pm 1,1$. Většina lymfocytů v synoviální tekutině byla charakteristická expresí CD45RA isoformy $(69,4 \pm 16,7)$. Tato studie je prvním krokem k následným analýzám změn v tomto kompartmentu vyvolaným onemocněním kloubů různé etiologie.

\section{Acknowledgements}

Supported by the Ministry of Education, Youth and Sports of the Czech Republic (Research Project No. 161700002) and by the Ministry of Agriculture of the Czech Republic (Grant No. MZE 0002716201).

\section{References}

AL-JANADI, M, AL-BALLA, S, AL-DALAAN, A, RAZIUDDIN, S 1993: Cytokine production by helper T cell populations from the synovial fluid and blood in patients with rheumatoid arthritis. J Rheumatol 20: 1647-1653 BARI, ASM, CARTER, SD, BELL, SC, MORGAN, K, BENNETT, D 1989: Anti-type II collagen antibody in naturally occuring canine joint diseases. Br J Rheumatol 28: 480-486

BELL, SC, HUGHES, DE, BENNETT, D, BARI, ASM, KELLY, DF, CARTER, SD 1997: Analysis and significances of anti-nuclear antibodies in dogs. Res Vet Sci 62: 83-84

BENNETT, D 1987a: Immune-based erosive inflammatory joint disease of the dog: canine rheumatoid arthritis 1. Clinical, radiological and laboratory investigations. J Small Anim Pract 28: 779-797

BENNETT, D 1987b: Immune-based erosive inflammatory joint disease of the dog: canine rheumatoid arthritis 2. Pathological investigations. J Small Anim Pract 28: 799-819

BENNETT, D 1987c: Immune-based non-erosive inflammatory joint disease of the dog 1. Canine systemic lupus erythematosus. J Small Anim Pract 28: 871-889

BENNETT, D 1987d: Immune-based non-erosive inflammatory joint disease of the dog 3. Canine idiopathic polyarthritis. J Small Anim Pract 28: 909-928 
BENNETT, D, KELLY, DF 1987: Immune-based non-erosive inflammatory joint disease of the dog 2. Polyarthritis/polymyositis syndrome. J Small Anim Pract 28: 891-908

BENNETT, D, TAYLOR, DJ 1987: Bacterial infective arthritis in the dog. J Small Anim Pract 29: 207-230

BENNETT, D, MAY, C 1985: Joint diseases of dogs and cats. In: Textbook of Veterinary Internal Medicine (Ettinger, S.J., Feldman, E.C., Eds.), W.B. Saunders, Philadelphia, pp. 2032-2076

BERTOUCH, JV, ROBERTS-THOMSON, PJ, BROOKS, PM, BRADLEY, J 1984: Lymphocyte subsets and inflammatory indices in synovial fluid and blood of patients with rheumatoid arthritis. J Rheumatol 11: 754-759 CARTER, SD, BELL, SC, BARI, ASM, BENNETT, D 1989: Immune complexes and rheumatoid factors in canine arthrities. Ann Rheum Dis 48: 986-991

COSTELlO, P, BRESNIHAN, B, O'FARRELly, C, FITZGERALD, O 1999: Predominance of CD8+ T lymphocytes in psoriatic arthritis. J Rheumatol 26: 1117-1124

DIRSCHERL, P, BEISKER, W, KREMMER, E, MIHALKOV, A, VOSS, C, ZIESENIS, A 1995: Immunophenotyping of canine bronchoalveolar and peripheral blood lymphocytes. Vet Immunol Immunopathol 48: 1-10

FALDYNA, M, LEVA, L, KNOTIGOVA, P, TOMAN, M 2001: Lymphocyte subsets in the peripheral blood of dogs - flow cytometry detection. Vet Immunol Immunopathol 82: 23-37

HEWICKER-TRAUTWEIN, M, CARTER, SD, BENNETT, D, KELLY, DF 1999: Immunocytochemical demonstration of lymphocyte subsets and MHC class II antigen expression in synovial membranes from dogs with rheumatoid arthritis and degenerative joint disease. Vet Immunol Immunopathol 67: 341-357

KEYSTONE, EC, RITTERSHAUS, C, WOOD, N, SNOW, KM, FLATOW, J, PURVIS, JC, POPLONSKI, L, KUNG, PC 1991: Elevation of a gamma delta T cell subset in peripheral blood and synovial fluid of patient with rheumatoid arthritis. Clin Exp Immunol 84: 78-82

KURYLISZYN-MOSKAL, A 1995: Comparation of blood and synovial fluid lymphocyte subsets in rheumatoid arthritis and osteoarthritis. Clin Rheumatol 14: 43-50

KUSABA, M, HONDA, J, FUKUDA, T, OIZUMI, K 1998: Analysis of type 1 and type 2 T cells in synovial fluid and peripheral blood of patients with rheumatoid arthritis. J Rheumatol 25: 1466-1471

MAY, C, HUGHES, DE, CARTER, SD, BENNETT, D 1992: Lymphocyte populations in the synovial membranes of dogs with rheumatoid arthritis. Vet Immunol Immunopathol 31: 289-300

NIEBAUER, GW, MENZEL, EJ 1982: Immunological changes in canine cruciate ligament rupture. Res Vet Sci 32: $235-241$

NIEBAUER, GW, WOLF, B, BASHEY, RI, NEWTON, CD 1987: Antibodies to canine collagen type I and II in dogs with spontaneous crutiate ligament rupture and osteoarthritis. Arthritis Rheum 30: 319-327

PANAYI, GS, LANCHBURY, JS, KINGSLEY, GH 1992: The importance of the T-cell in initiating and maintaining the chronic synovitis of rheumatoid arthritis. Arthritis Rheum 35: 729-735

REME, T, PORTIER, M, FRAYSSINOUX, F, COMBE, B, MIOSSEC, P, FAVIER, F, SANY, J 1990: T cell receptor expression and activation of synovial lymphocyte subsets in patients with rheumatoid arthritis. Phenotyping of multiple syovial sites. Arthritis Rheum 33: 485-492

SCHUMACHER, HR, NEWTON, C, HALLIWELL, RE 1980: Synovial pathologic changes in spontaneous canine rheumatoid-like arthritis. Arthritis Rheum 23: 412-423

SMEETS, TJ, DOLHAIN, RJ, BREEDVELD, FC, TAK, PP 1998: Analysis of the cellular infiltrates and expression of cytokines in synovial tissue from patients with rheumatoid arthritis and reactive arthritis. J Pathol 186: $75-81$

SOHEN, S, ROMAIN, PL, ROTHSTEIN, DM, YAMANE, T, TANAKA, S, ANDERSON, P, SCHLOSSMAN, SF, MORIMOTO, C 1991: Phenotypic abnormalities in CD8+ T lymphocyte subsets in patients with rheumatoid arthritis. J Rheumatol 18: 1649-1654

TIPOLD, A, MOORE, P, JUNGI, TW, SAGER, H, VANDEVELDE, M 1998: Lymphocyte subsets and CD45RA positive T-cells in normal canine cerebrospinal fluid. J Neuroimmunol 82: 90-95

VAIL, DM, MAHLER, PA, SOERGEL, SA 1995: Differential cell analysis and phenotypic subtyping of lymphocytes in bronchoalveolar lavage fluid from clinically normal dogs. Am J Vet Res 56: 282-285

YAMAMURA, Y, GUPTA, R, MORITA, Y, HE, X, PAI, R, ENDRES, J, FREIBERG, A, CHUNG, K, FOX, DA 2001: Effector function of resting T cells: activation of synovial fibroblasts. J Immunol 166: 2270-2275 